\title{
Sciendo
}

DOI: $10.1515 /$ sspjce-2019-0022

\section{Degradation model of turnout wear according to frog material}

\author{
Ján Urda, Ján Mandula \\ Technical University of Košice, Slovakia \\ Civil Engineering Faculty, Institute of Structural Engineering \\ e-mail: urda.jan@zsr.sk,jan.mandula@tuke.sk
}

\begin{abstract}
This paper describes the evaluation of the measured data from the turnout wear in relation to material from which the frogs are made. The evaluation consists in comparing the measured results with the data provided by the manager of these turnouts.
\end{abstract}

Key words: turnouts, rail, vertical wear, correlation analysis, regression analysis

\section{Introduction}

The basic and important condition for efficient management and maintenance of the railway infrastructure is to know its real condition. The way to this knowledge is the system of measurement, monitoring and diagnostics of the railway infrastructure.

One of the method of turnout diagnostics is also measuring the wear of mobile components, especially tongues and frogs. Excessive wear of frogs, especially on modernized sections of ŽSR lines is becoming an increasing problem. ŽSR Research and Development Institute of Railways in Žilina, within the framework of research and development tasks, monitors the frogs of 40 turnouts on the ŽSR network in the district of the Regional Directorate Trnava.

\section{Scope of monitoring}

Within the monitoring, 40 pieces of frogs were selected in the railway stations: Vel'ké Kostol'any (6 pcs), Piešt’any (7 pcs), Nové Mesto nad Váhom (6 pcs), Leopoldov (8 pcs), Brestovany (4 pcs) and Trnava (9 pcs).

Due to the limited scope of the paper, only measurements of frog wear in relation to the material from which frogs are made are evaluated here. CONTOUR laser device (Figure 1) was used to measure wear. 




Figure 1: CONTOUR device

The following parameters were measured on turnouts:

- horizontal wear,

- vertical wear,

- wing rail wear,

- wear of crossing nose,

- flangeway width,

- flangeway depth.

According to the ŽSR valid Regulation "TS 3 Railway superstructure", it is allowed during operation the greatest vertical wear of the frog at the place where the nose width is $40 \mathrm{~mm}$ and more, at the permitted speed:

- $\mathrm{V} \geq 100 \mathrm{~km} / \mathrm{h}$, not more than $6 \mathrm{~mm}$,

- $40 \mathrm{~km} / \mathrm{h}<\mathrm{V}<100 \mathrm{~km} / \mathrm{h}$, not more than $9 \mathrm{~mm}$,

- $\mathrm{V} \leq 40 \mathrm{~km} / \mathrm{h}$, not more than $12 \mathrm{~mm}$.

The values of frog vertical wear are measured in the longitudinal direction as the difference between the top of the point rail and point of measurement at the crossing nose where its width is $40 \mathrm{~mm}$ (Figure 2).

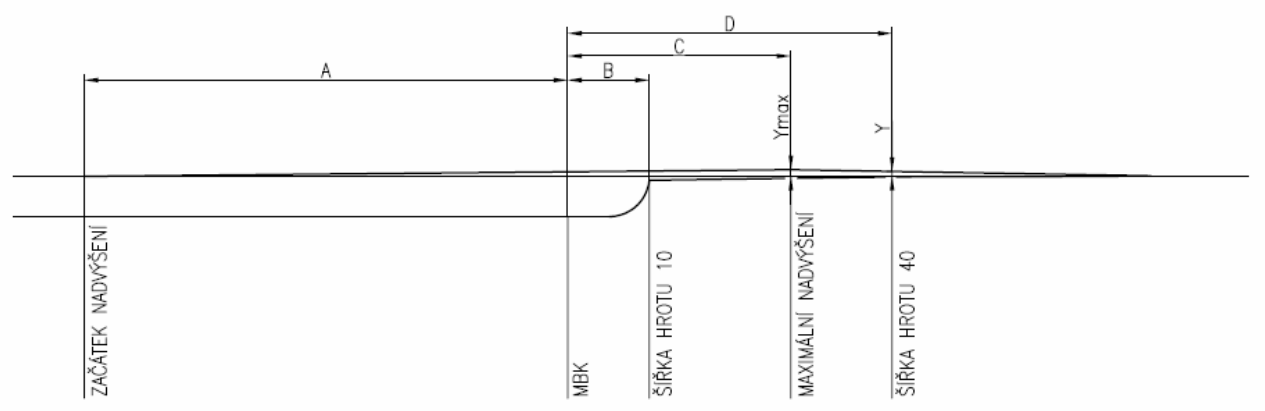

Figure 2: Longitudinal section of frog

In the next section, we will focus on the evaluation of wear of the monitored set of frogs depending on material from which they are made according to Table 1. 
Table 1: Classification of measured turnouts according to frog material

\begin{tabular}{|c|c|c|c|c|c|c|}
\hline \multirow{2}{*}{ Order } & \multirow{2}{*}{ Railway station } & \multirow{2}{*}{$\begin{array}{c}\text { Number of } \\
\text { turnouts }\end{array}$} & \multirow{2}{*}{ Turnout type } & \multicolumn{3}{|c|}{ Frog's steel } \\
\hline & & & & Rail & Manganese & Bainitic \\
\hline 1. & Vel'ké Kostol'any & 4 & J $601: 9300$ & & $x$ & \\
\hline 2. & Vel'ké Kostol'any & 5 & J $601: 9300$ & & $\mathrm{x}$ & \\
\hline 3. & Vel'ké Kostol'any & 11 & J $601: 9300$ & & $\mathrm{x}$ & \\
\hline 4. & Vel'ké Kostol'any & 13 & J 60 1:14 760 & & $\mathrm{x}$ & \\
\hline 5. & Vel'ké Kostol'any & 16 & J 60 1:14 760 & & $\mathrm{x}$ & \\
\hline 6. & Vel'ké Kostol'any & 15 & J 60 1:14 760 & & $\mathrm{x}$ & \\
\hline 7. & Piešt’any & 4 & J 60 1:18,5 1200 & & $\mathrm{x}$ & \\
\hline 8. & Piešt'any & 6 & J 60 1:14 760 & & $\mathrm{x}$ & \\
\hline 9. & Piešt’any & 15 & J $601: 14760$ & & $\mathrm{x}$ & \\
\hline 10. & Piešt’any & 11 & J $601: 14760$ & & $\mathrm{x}$ & \\
\hline 11. & Piešt’any & 1 & J 60 1:18,5 1200 & & & $\mathrm{x}$ \\
\hline 12. & Piešt’any & 18 & J 60 1:14 760 & & $\mathrm{x}$ & \\
\hline 13. & Piešt’any & 20 & J 60 1:12-500 & & $\mathrm{x}$ & \\
\hline 14. & Nové Mesto n. V. & 16 & J $601: 9300$ & & $\mathrm{x}$ & \\
\hline 15. & Nové Mesto n. V. & 1 & J 60 1:18,5 1200 & & $\mathrm{x}$ & \\
\hline 16. & Nové Mesto n. V. & 4 & J $601: 9300$ & & $\mathrm{x}$ & \\
\hline 17. & Nové Mesto n. V. & 5 & J 60 1:18,5 1200 & & $\mathrm{x}$ & \\
\hline 18. & Nové Mesto n. V. & 50 & J 60 1:18,5 1200 & & $\mathrm{x}$ & \\
\hline 19. & Nové Mesto n. V. & 43 & J $601: 11300$ & & $\mathrm{x}$ & \\
\hline 20. & Leopoldov & 4 & J 60 1:18,5 1200 & & & $\mathrm{x}$ \\
\hline 21. & Leopoldov & 22 & J S49 1:9 300 & $\mathrm{x}$ & & \\
\hline 22. & Leopoldov & 23 & J S49 1:14 760 & $\mathrm{x}$ & & \\
\hline 23. & Leopoldov & 6 & J S49 1:9 300 & $\mathrm{x}$ & & \\
\hline 24. & Leopoldov & 11 & J 60 1:14 760 & & & $\mathrm{x}$ \\
\hline 25. & Leopoldov & 15 & Ob $601: 14760$ & & & $\mathrm{x}$ \\
\hline 26. & Leopoldov & 17 & Ob 60 1:14 760 & & & $\mathrm{x}$ \\
\hline 27. & Leopoldov & 13 & J 60 1:14 760 & & & $\mathrm{x}$ \\
\hline 28. & Brestovany & 1 & J 60 1:18,5 1200 & & $\mathrm{x}$ & \\
\hline 29. & Brestovany & 2 & J 60 1:18,5 1200 & & $\mathrm{x}$ & \\
\hline 30. & Brestovany & 3 & J 60 1:18,5 1200 & & $\mathrm{x}$ & \\
\hline 31. & Brestovany & 4 & J 60 1:18,5 1200 & & $\mathrm{x}$ & \\
\hline 32. & Trnava & 81 & J $601: 9300$ & & & $\mathrm{x}$ \\
\hline 33. & Trnava & 82 & J 60 1:12500 & & & $\mathrm{x}$ \\
\hline 34. & Trnava & 96 & J 60 1:18,5 1200 & & & $\mathrm{x}$ \\
\hline 35. & Trnava & 92 & J 60 1:18,5 1200 & & & $\mathrm{x}$ \\
\hline 36. & Trnava & 97 & J 60 1:18,5 1200 & & & $\mathrm{x}$ \\
\hline 37. & Trnava & 87 & J $601: 11300$ & & & $\mathrm{x}$ \\
\hline 38. & Trnava & 86 & J 60 1:12 500 & & & $\mathrm{x}$ \\
\hline 39. & Trnava & 78 & J 60 1:12 500 & & & $\mathrm{x}$ \\
\hline 40. & Trnava & 69 & J S49 1:12 500 & $\mathrm{x}$ & & \\
\hline
\end{tabular}


Based on material analysis, according to Table 2, the frogs are divided into three groups of steel:

- rail,

- manganese,

- bainitic.

Table 2: Division of the sample according to the frog material

\begin{tabular}{|c|c|c|c|}
\hline Type of steel & rail & manganese & bainitic \\
\hline Number & 4 & 22 & 14 \\
\hline
\end{tabular}

\section{Evaluation according to material from which the frog is made}

The high demands are placed on steels for the manufacture of mobile turnout components, mainly on impact resistance, toughness, abrasion, adhesion and corrosion wear resistance. Most often, frogs are made of classic rail steel, austenitic manganese steel, perlitized steel and bainitic steel.

\subsection{Evaluation of turnouts with rail steel frogs}

To determine the regression equation of dependence of the maximum value of the determining quantity and the time, 24 measurements are included for this turnout shape.

A graphical representation of the relations of correlation and regression analyses according to criterion of frog material $h_{v} / t$ is shown in Figure 3. The calculation of the shortest frog degradation time is described by a linear equation (1).

$$
t=\frac{\left|h_{v}\right|_{\text {lim }}+0,0305}{0,0145} \text { (months) }
$$



Figure 3: Graphical representation of relations of correlation and regression analyses $\left|h_{v}\right| \mathrm{lim} / t$ of turnouts with rail steel frogs 
Table 3: Linear course of wear of turnouts with rail steel frogs

\begin{tabular}{|c|c|c|c|c|c|c|c|c|}
\hline Type of steel & $\boldsymbol{n}$ & $\boldsymbol{a}$ & $\boldsymbol{b}$ & $\boldsymbol{c}$ & $\boldsymbol{R}_{\alpha, 0,05}$ & $\boldsymbol{R}$ & Complies? & Course \\
\hline rail & 24 & 0,0305 & 0,0145 & - & 0,4044 & 0,624 & yes & linear \\
\hline
\end{tabular}

Based on the results of the regression and correlation analyses of the relationship between the absolute value of the maximum determining quantity (vertical wear) and time, it can be assumed that the evaluated quantity will reach in time the limit value according to Regulation [1] over 52 years, provided that the current state of the $3^{\text {rd }}$-order operating load and maintenance, i.e. regular grinding, inter alia, with a period of once a year, is maintained, while the lifetime of turnouts on the ŽSR network is expected to be $20-30$ years.

The accuracy of the prediction of the time to reach the determined degradation level $\left|h_{v}\right|$ lim can currently be denoted as lower $\left(\mathrm{R}^{2}=0.3888\right)$ but it can be assumed that it will increase by adding data from future measurements.

\subsection{Evaluation of turnouts with manganese steel frogs}

To determine the regression equation of dependence of the maximum value of the determining quantity and the time, 132 measurements are included for this turnout shape.

A graphical representation of the relations of correlation and regression analyses according to criterion of frog material $h_{v} / t$ is shown in Figure 4. The calculation of the shortest frog degradation time is described by the linear equation (2).

$$
t=\frac{\left|h_{v}\right|_{\text {lim }}+0,0782}{0,0333} \text { (months) }
$$

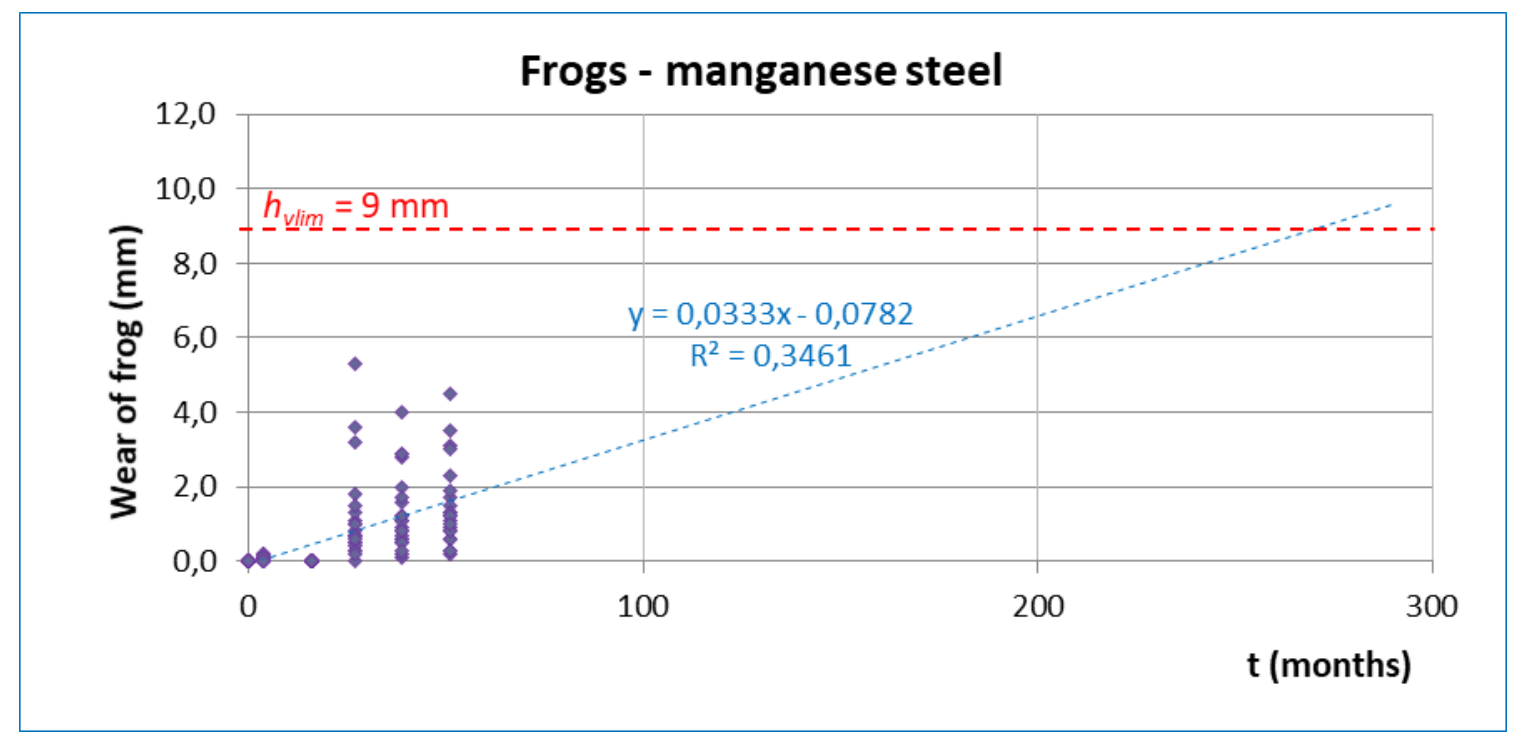

Figure 4: Graphical representation of relations of correlation and regression analyses $\left|h_{v}\right| \lim / t$ of turnouts with manganese steel frogs 
Table 4: Linear course of wear of turnouts with manganese steel frogs

\begin{tabular}{|c|c|c|c|c|c|c|c|c|}
\hline Type of steel & $\boldsymbol{n}$ & $\boldsymbol{a}$ & $\boldsymbol{b}$ & $\boldsymbol{c}$ & $\boldsymbol{R}_{\boldsymbol{a} \boldsymbol{0}, \boldsymbol{0 5}}$ & $\boldsymbol{R}$ & Complies? & Course \\
\hline manganese & 132 & 0,0782 & 0,0333 & - & 0,1627 & 0,588 & yes & linear \\
\hline
\end{tabular}

Based on the results of the regression and correlation analyses of the relationship between the absolute value of the maximum determining quantity (vertical wear) and time, it can be assumed that the evaluated quantity will reach in time the limit value according to Regulation [1] over a period of 23 years, provided that the current state of the $3^{\text {rd }}$-order operating load and maintenance, i.e. regular grinding, inter alia, with a period of once a year, is maintained, while the lifetime of turnouts on the ŽSR network is expected to be 20-30 years.

The accuracy of the prediction of the time to reach the determined degradation level $\left|h_{v}\right|$ im can currently be denoted as lower $\left(\mathrm{R}^{2}=0.3461\right)$ but it can be assumed that it will increase by adding data from future measurements.

\subsection{Evaluation of turnouts with bainitic steel frogs}

To determine the regression equation of dependence of the maximum value of the determining quantity and the time, 84 measurements are included for this turnout shape.

A graphical representation of the relations of correlation and regression analyses according to criterion of frog material $h_{v} / t$ is shown in Figure 5. The calculation of the shortest frog degradation time is described by the linear equation (3).

$$
t=\frac{\left|h_{v}\right|_{\text {lim }}+0,038}{0,0175}(\text { months })
$$

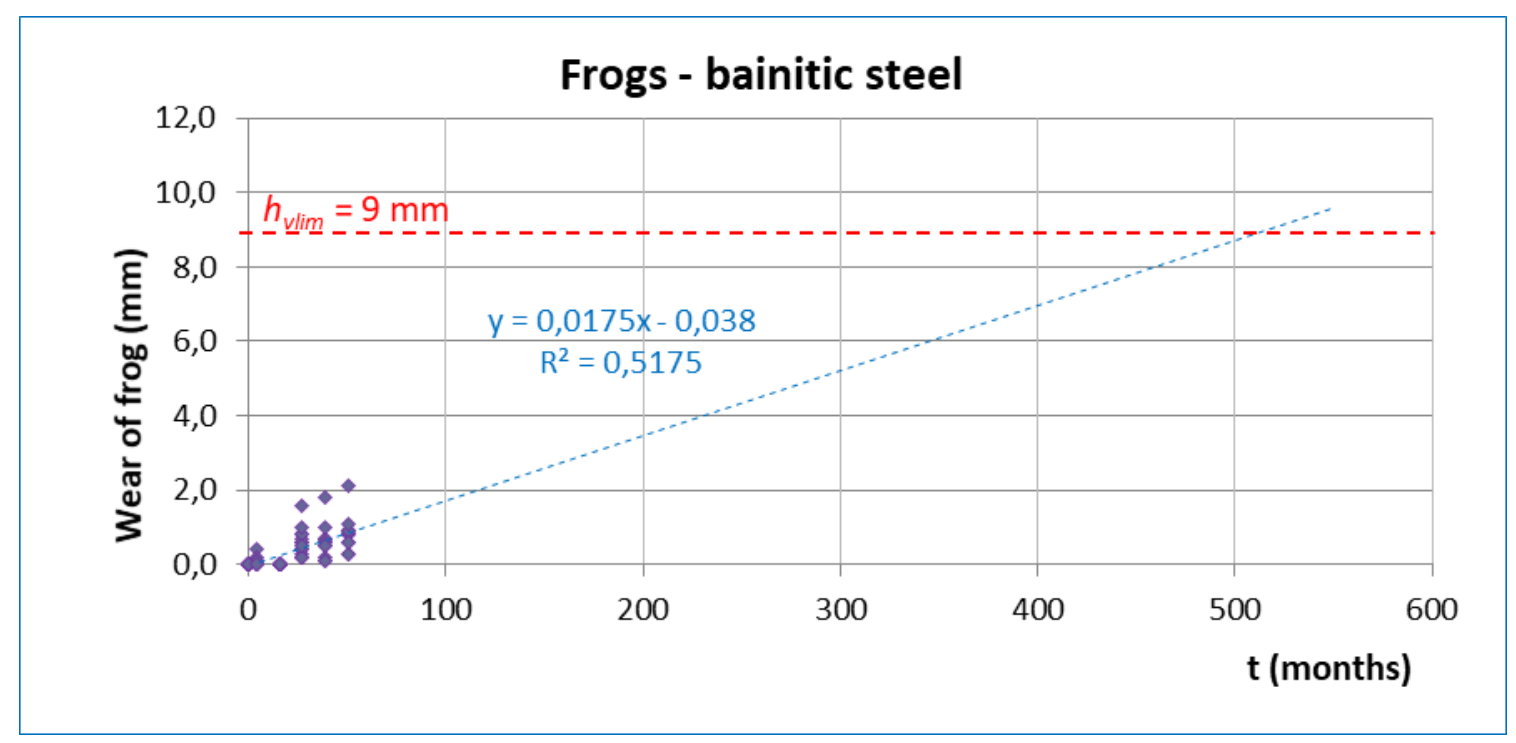

Figure 5: Graphical representation of relations of correlation and regression analyses $\left|h_{v}\right| \lim / t$ of turnouts with bainitic steel frogs 
Table 5: Linear course of wear of turnouts with bainitic steel frogs

\begin{tabular}{|c|c|c|c|c|c|c|c|c|}
\hline Type of steel & $\boldsymbol{n}$ & $\boldsymbol{a}$ & $\boldsymbol{b}$ & $\boldsymbol{c}$ & $\boldsymbol{R}_{\alpha, 0,05}$ & $\boldsymbol{R}$ & Complies? & Course \\
\hline bainitic & 84 & 0,038 & 0,0175 & - & 0,2148 & 0,719 & yes & linear \\
\hline
\end{tabular}

Based on the results of the regression and correlation analyses of the relationship between the absolute value of the maximum determining quantity (vertical wear) and time, it can be assumed that the evaluated quantity will reach in time the limit value according to Regulation [1] over a period of 43 years, provided that the current state of the $3^{\text {rd }}$-order operating load and maintenance, i.e. regular grinding, inter alia, with a period of once a year, is maintained, while the lifetime of turnouts on the ŽSR network is expected to be 20-30 years.

The accuracy of the prediction of the time to reach the determined degradation level $\left|h_{v}\right|$ lim can currently be denoted as intermediate $\left(\mathrm{R}^{2}=0.5175\right)$ but it can be assumed that it will increase by adding data from future measurements.

\section{Evaluation}

When comparing the impact of grinding or non-grinding of frogs in relation to material from which the frog is made, the manganese steel frogs were achieved the greatest wear $(5.3 \mathrm{~mm})$ and the lowest values were achieved by rail steel frogs $(1.5 \mathrm{~mm}$ ) (Figure 6). The limit value of wear would achieve first the manganese steel frogs in 23 years and at latest the rail steel frogs in 52 years.

Table 6: Evaluation according to frog material

\begin{tabular}{|l|c|c|c|c|}
\hline \multirow{2}{*}{ Frog's steel } & \multirow{2}{*}{$\mathbf{R}^{\mathbf{2}}$} & $\begin{array}{c}\text { Reaching limit value of } \\
\text { wear according to } \\
\text { Regulation [1] [year] }\end{array}$ & \multicolumn{2}{|c|}{ Lifetime order } \\
\cline { 4 - 5 } & & & evaluated & manager \\
\hline rail & 0,3888 & 52 & 3. & 3. \\
\hline bainitic & 0,5175 & 43 & 2. & 2. \\
\hline manganese & 0,3461 & 23 & 1. & 1. \\
\hline
\end{tabular}

When comparing the results obtained with the data from the manager, we can conclude that these results coincide since he declared that the frogs of manganese steel withstand them the least, then the bainitic steel frogs and finally the rail steel frogs (Table 6).

In the case of manganese frogs it is also necessary to take into account the fact that ŽSR has not yet ground the decaburized layers, which need to be grind after the frog has been run in operation, therefore they have a low lifetime. 


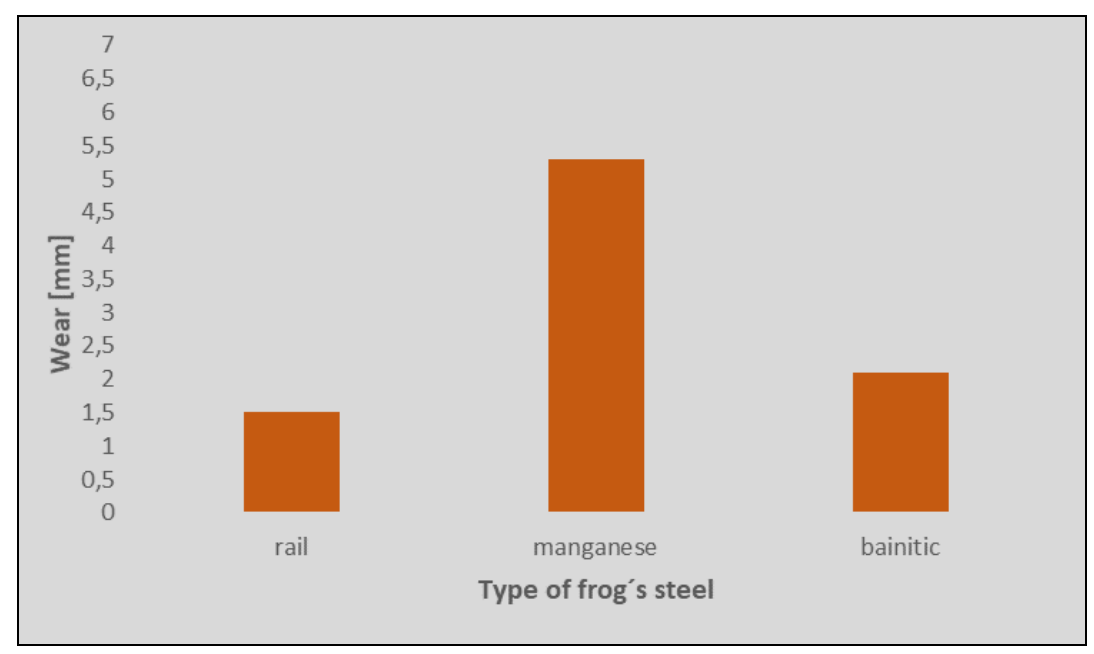

Figure 6: Graphical representation of measured maximum wear according to frog material

\section{Conclusion}

When evaluating the results in relation to the material from which the frog is made, it can be concluded that the manganese steel frogs achieved the greatest wear ant the lowest values were achieved by the rail steel frogs. The limit value of wear would achieve first the manganese steel frogs and at latest the rail steel frogs. When comparing the results with the data from the manager, we can conclude that these results coincide since he declared that the frogs of manganese steel withstand them the least, then the bainitic steel frogs and finally the rail steel frogs (Table 6).

\section{References}

[1] Regulation ŽSR TS 3 Railway superstructure

[2] Urda, J., Mandula, J., Urdová, A. Degradation model of wear frogs switches on the tracks ŽSR. XXIV R-S-P seminar, Theoretical Foundation of Civil Engineering. 24.-28. August 2015, Samara, Russia

[3] Urda, J., Mandula, J. Príspevok k modelovaniu opotrebovania srdcoviek výhybiek. 7. Medzinárodná vedecká konferencia pozemného stavitel'stva a architektúry „Mladý vedec 2015“, 08.-10.04.2015, Jasná

[4] Urda, J., Klučka, M. Novelizácia predpisov ŽSR o meraní výhybiek a brúsení. 18. seminár trat’ového hospodárstva STRAHOS 2018, 19. - 20. apríl 2018, Banská Bystrica

[5] Urda, J., Mandula, J.: Degradation model of wear of frogs switches on the track. International journal of interdisciplinary in theory and practise. Nr.: 8 Year: 2015, Romania, ISSN: $2344-$ 2409, ISSN-L: 2344 - 2409 